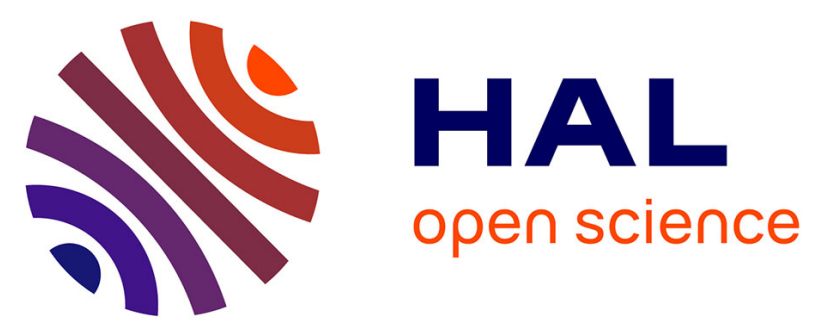

\title{
Characterization of At- species in simple and biological media by high performance anion exchange chromatography coupled to gamma detector.
}

A. Sabatié-Gogova, Julie Champion, Sandrine Huclier, Nathalie Michel, F. Pottier, N. Galland, Z. Asfari, M. Chérel, Gilles F Montavon

\section{To cite this version:}

A. Sabatié-Gogova, Julie Champion, Sandrine Huclier, Nathalie Michel, F. Pottier, et al.. Characterization of At- species in simple and biological media by high performance anion exchange chromatography coupled to gamma detector.. Analytica Chimica Acta, 2012, 721, pp.182. 10.1016/j.aca.2012.01.052 . in2p3-00681129

\section{HAL Id: in2p3-00681129 \\ https://hal.in2p3.fr/in2p3-00681129}

Submitted on 20 Mar 2012

HAL is a multi-disciplinary open access archive for the deposit and dissemination of scientific research documents, whether they are published or not. The documents may come from teaching and research institutions in France or abroad, or from public or private research centers.
L'archive ouverte pluridisciplinaire HAL, est destinée au dépôt et à la diffusion de documents scientifiques de niveau recherche, publiés ou non, émanant des établissements d'enseignement et de recherche français ou étrangers, des laboratoires publics ou privés. 
1 Characterization of At $^{-}$species in simple and biological media by high performance anion exchange chromatography coupled to gamma detector.

3

4

5 6 Asfari $^{\mathrm{c}}, \mathrm{M}$. Chérel $^{\mathrm{d}}, \mathrm{G}$. Montavon $^{\mathrm{a}}{ }^{*}$

7

8

9

10

11

12

13

14

15

16

17

18

19

20

21

22

23

Abstract

24 asfariz@ecpm.u-strasbg.fr

\section{Abstract}

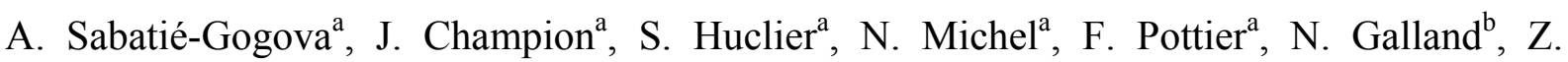

${ }^{\text {a }}$ Laboratoire SUBATECH, UMR CNRS 6457 IN2P3 Ecole des Mines de Nantes, 4 rue A. Kastler, $44307 \quad$ Nantes $\quad$ Cedex, $\quad$ France. $\quad \underline{\text { sabatie } @ \text {,subatech.in2p3.fr, }}$ champion@subatech.in2p3.fr, $\quad$ pottier@subatech.in2p3.fr, $\quad$ ledu@subatech.in2p3.fr, huclier@subatech.in2p3.fr, michel@subatech.in2p3.fr

${ }^{\mathrm{b}}$ Laboratoire CEISAM, UMR CNRS 6230, Université de Nantes, 2 rue de la Houssinière, 44322 Nantes Cedex, France. nicolas.galland@univ-nantes.fr

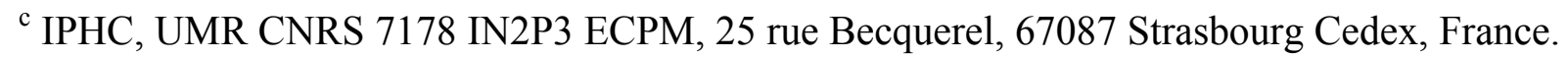

${ }^{\text {d }}$ IRT UN INSERM 892 CRCNA, Université de Nantes, 8 quai Moncousu 44093, Nantes Cedex, France. Michel.Cherel@univ-nantes.fr

Keywords: Astatine, speciation, ion-exchange, human serum 4 
Astatine is a rare radioelement belonging to the halogen group. Considering the trace 26 amounts of astatine produced in cyclotrons, its chemistry cannot be evaluated by 27 spectroscopic tools. Analytical tools, provided that they are coupled with a radioactive 28 detection system, may be an alternative way to study its chemistry. In this research work, 29 High Performance Anion Exchange Chromatography (HPAEC) coupled to a gamma detector $30(\gamma)$ was used to evaluate astatine species under reducing conditions. Also, to strengthen the 31 reliability of the experiments, a quantitative analysis using a reactive transport model has been 32 done. The results confirm the existence of one species bearing one negative charge in the $\mathrm{pH}$ 33 range 2-7.5. With respect to the other halogens, its behavior indicates the existence of 34 negative ion, astatide At ${ }^{-}$. The methodology was successfully applied to the speciation of the 35 astatine in human serum. Under fixed experimental conditions ( $\mathrm{pH}$ 7.4-7.5 and redox 36 potential of $250 \mathrm{mV}$ ) astatine exists mainly as astatide $\mathrm{At}^{-}$and does not interact with the major 37 serum components. Also, the method might be useful for the in vitro stability assessment of $38 \quad{ }^{211}$ At-labelled molecules potentially applicable in nuclear medicine. 


\section{INTRODUCTION}

42

Astatine (At), element 85, is below iodine in the periodic table of elements. It is a rare element representing short half-life radioactive isotopes that have to be produced in cyclotrons [1].

${ }^{211} \mathrm{At}$ is of considerable interest as it is a promising radiotherapeutic agent for targeted alpha therapy (TAT) in nuclear medicine [2-4]. In this field, the astatination through diazo intermediates under non-oxidizing mild conditions has been suggested to react with astatine anionic or radical species $[5,6]$. The general approach developed more recently has been the use of bifunctional reagents conjugated to the proteins and labelled, similarly to the radioiodination, under oxidizing conditions of Chloramine $\mathrm{T}$, hydrogen peroxide or $\mathrm{N}$ iodosuccinimide with astatine cationic reactive species [2-7].

Astatinated molecules as well the bio-conjugates are quite unstable in vivo relative to their radioiodinated analogues [7]. Due to the fact that released astatine localizes in thyroid in humans, as iodide, iodate, chlorate, or pertechnetate [5] the form of astatide ( $\left.\mathrm{At}^{-}\right)$has been proposed. Furthermore, the distribution (in PBS) between plasma and blood cells in vitro has established that it is poorly entrapped within the erythrocytes, which render it available for the transport in the blood [8]. The mechanism of "deastatination" in vivo remains still unknown, Wilbur has only pointed out the complex character of probably enzymatic, biochemical and/or physical process [7]. The stability is generally assessed using in vitro studies with blood serum by thin layer chromatography. Although the method is rapid, it gives no indication about astatine speciation. 
Astatine chemistry remains generally not well understood. It is an invisible element: the produced amount of astatine allows only ultra trace concentrations (typically $10^{-11}$ to $10^{-15}$ mol L $\mathrm{L}^{-1}$ ) and thus no spectroscopic tools can be used to investigate astatine chemistry at the molecular level. In reducing conditions, astatine presents some other similarities with respect to its homologues of the halogen group, especially iodine. For example, it coprecipitates with insoluble iodide compounds $[9,10]$ and astatine forms the hydrogen astatide (HAt) alike the halogens form hydrogen halides. The identification of $\mathrm{HAt}^{+}$and $\mathrm{HI}^{+}$species in gas phase by mass spectrometry [11] may be an indirect proof of the presence of $\mathrm{At}^{-}$. Astatide $\left(\mathrm{At}^{-}\right)$is therefore an expected species in various media. Surprisingly, only a few people have endeavored to identify the astatide by means of analytical tools. The negative charge of astatine species has been deduced from its ability to be retained by anionic exchanger Aminex A27 [12-14], and from electromobility measurements [15]. Berei et al. [5], using the data of Roessler [14]from high-pressure liquid radiochromatography experiments, showed a linear correlation between the retention volume and the inverse ionic radius for halogens and concluded that the astatine species under study behave as halogenide At. However, as it will be discussed later, due to the proportionality of the retention volume to the selectivity coefficient, the correlation should show an exponential curve trend. This discrepancy makes the results of Roessler et al. questionable and new data are needed.

In this paper, the first objective is to acquire new data by high-performance anionexchange chromatography under reducing conditions using simple media $0.01-0.10 \mathrm{~mol} \mathrm{~L}^{-1}$ $\mathrm{H} / \mathrm{NaCl}$ (chloride as the exchange species) with $\mathrm{pH}$ values ranging from 2.0 to 7.5 for a better identification of astatine species. For comparison, experiments are also performed with other halogens anions $\left(\mathrm{F}^{-}, \mathrm{Br}^{-}, \mathrm{I}^{-}\right)$. To help the evaluation of experimental data, a quantitative analysis using the reactive transport code PHREEQC [16] is proposed. Then, the second objective is to apply the methodology for speciation of astatine in blood serum. At $\mathrm{pH}$ of 7.4 

9

its potential varies between 200 and $300 \mathrm{mV}$ versus NHE (Normal Hydrogen Electrode) [17] which coincide with the values related to the existence of thermodynamically stable anionic astatine species.

\section{EXPERIMENTAL}

\subsection{Materials}

Commercially available chemical products of analytical grade or superior were purchased from Sigma-Aldrich. Transferrin from human blood plasma $(\geq 95 \%)$ and albumin from human blood plasma ( $\geq 99 \%$ ) were also purchased from Sigma-Aldrich. Human serum was supplied by Lonza.

${ }^{211}$ At was produced by the nuclear reaction ${ }^{209} \mathrm{Bi}(\alpha, 2 \mathrm{n}){ }^{211}$ At at the CEMTHI cyclotron (Orléans, France). Bismuth (Bi) target was prepared by the evaporation of bismuth under vacuum onto nitride aluminium backing (shapal-M from Goodfellow). The ceramic backing has good thermal properties and is heat resistant under beam. An elliptical deposit with a surface area of $3 \mathrm{~cm}^{2}$ and a homogeneous thickness between 22.3 and $30.0 \mu \mathrm{m}$ was obtained within few hours. The homogeneity of the deposit was checked using a profilometric analysis. Run duration as well as beam intensity were adapted to reach needed ${ }^{211}$ At activity. For the present work, duration run varied from 2 to 3 hours and beam intensity from 1.7 to $2.3 \mu \mathrm{A}$ leading to production from 100 to $317 \mathrm{MBq}$ at the end of bombardment. 
Detailed information about the production can be found elsewhere [18,19]. Astatine from

114 the target was recovered by dry distillation and captured in methanol (yield at about $80 \%$ )

115 [19]. The radionuclide purity was monitored using $\gamma$-ray spectroscopy. In order to lower the

116 X-ray contribution, a lead shielding was placed between the detector and the sample.

117 Typically, the stock solutions were obtained with a specific activity close to $100 \mathrm{MBq} \mathrm{mL}^{-1}$.

118 The radiotracer ${ }^{131} \mathrm{I}$ was obtained diluted in water with a specific activity close to $0.1 \mathrm{MBq}$

$119 \mathrm{~mL}^{-1}$ from the CHU Nuclear Medicine (Nantes, France).

\subsection{Analytical tools}

The radionuclidic purity of ${ }^{211}$ At was monitored by $\gamma$-ray spectrometry with a high purity germanium (HPGe) detector. The activity of the stock astatine solution was measured on both the $\mathrm{X}$-rays from ${ }^{211} \mathrm{Po}$ and ${ }^{211} \mathrm{At}$ and $\gamma$-rays at $687.00 \mathrm{keV}$ from ${ }^{211} \mathrm{At}$, using a suitable

128 geometry previously calibrated with standard gamma sources. ${ }^{211}$ At recovery after the

129 HPAEC $-\gamma$ measurements was quantified by liquid scintillation counting using a Packard 2550 TR/AB liquid scintillation analyzer with the Ultima Gold LLT scintillation liquid.

A Fisherbrand type electrode freshly calibrated against dilute standard $\mathrm{pH}$ buffers $(\mathrm{pH} 1-$ 10, Merck) was used to determine the $\mathrm{pH}$. The potential (E) of aqueous solutions was

133 measured using a Pt combined redox electrode (Metrohm type) calibrated against the redox 134 buffer $\left(\mathrm{Fe}(\mathrm{SCN})_{6}^{-3} / \mathrm{Fe}(\mathrm{SCN})_{6}^{-4}, 215 \mathrm{mV} / \mathrm{Pt} / \mathrm{SCE}\right.$, Radiometer Analytical).

135 The HPLC device is a Dionex UltiMate3000 system consisting of a DGP-3600 MB pump, 136 an AS3000 auto-sampler, a TCC-3200B column oven and a diode array DAD-3000 detector.

137 The stationary phase is a Dionex AS20 anionic exchange column $(0.2 \mathrm{~cm}$ diameter $\times 25 \mathrm{~cm}$ 
138 length), with an AG20 guard column $(0.2 \mathrm{~cm}$ diameter $\times 5 \mathrm{~cm}$ length $)$. The AS20 consists of a

139 hydrophilic polymer grafted with quaternary alkanol ammonium. The total capacity 140 represented by both columns is 0.079 milliequivalents (meq). The degree of Cross-Linking (\% 141 of DiVinylBenzene, \%DVB) amounts to $55 \%$. The resin was designed for working in $\mathrm{NaOH}$ 142 or $\mathrm{KOH}$ media. However, taking into account the context of the study, the sodium chloride 143 medium was chosen (see 2.3. Experimental procedure). The $\gamma$-ray detector is a Raytest 144 GabiStar, piloted by Gina Software. Count rate is $0-500.000$ cps. The detection energy 145 window was set between 50 and $1630 \mathrm{keV}$. Experimental data were acquired and processed 146 by Chromeleon 6.80 Chromatograph Software.

147 The components in stock solutions and collected fractions were quantified by Inductively 148 coupled plasma mass spectrometry (ICPMS) XSERIES2 Thermo Scientific for I', by Ion 149 Chromatography (IC) with conductivity detection ICS 2500 from Dionex for $\mathrm{F}^{-}$and $\mathrm{Br}^{-}$, and 150 by UV-VIS Spectrophotometer UV-1800 Shimadzu for albumin and transferrin by using the 151 absorption coefficients of $9.30 \times 10^{4}$ and $3.53 \times 10^{4} \mathrm{~cm}^{-1} \mathrm{~mol}^{-1} \mathrm{~L}$ at $280 \mathrm{~nm}$, respectively [20].

\subsection{Experimental procedures}

The solutions and eluents were freshly prepared using degassed (by ultrasonics) Milli-Q deionized water under argon atmosphere. Astatine is a redox-sensitive species [21]. In all

159 eluents, the redox couple $\mathrm{SO}_{3}{ }^{2-} / \mathrm{S}_{2} \mathrm{O}_{3}{ }^{2-}\left(10^{-4} / 10^{-3}\right.$ mol L $\left.{ }^{-1}\right)$ was used to maintain the potential at $160250 \mathrm{mV}$ versus NHE (Normal Hydrogen Electrode). It is a mean value characterizing the 161 serum potential which varies between 200 and $300 \mathrm{mV}$ versus NHE [17]. For astatine-in162 blood serum assays, the eluent composition was close to the physiological solution $\left(10^{-1} \mathrm{~mol}\right.$ 
$\mathrm{L}^{-1} \mathrm{NaCl}, \mathrm{pH}$ 7.4). The $\mathrm{pH}$ was buffered with $10^{-3} \mathrm{~mol} \mathrm{~L}^{-1} \mathrm{PBS}$ that, as 10 -fold concentrate,

164 contains $10^{-1}$ mol L ${ }^{-1}$ of sodium phosphate $\left(\mathrm{Na}_{3} \mathrm{PO}_{4}\right)$ and $9 \%$ of $\mathrm{NaCl}$. For the other experiments, $10^{-1} \mathrm{~mol} \mathrm{~L}^{-1} \mathrm{NaCl}$ (with or without $10^{-2} \mathrm{~mol} \mathrm{~L}^{-1} \mathrm{HCl}$ ) was used unless otherwise stated. Eluents were kept under argon flow during proceedings.

167 The stock solutions were prepared by dissolving the appropriate mass of $\mathrm{NaX}(\mathrm{X}=\mathrm{F}, \mathrm{Cl}$,

$168 \mathrm{Br}, \mathrm{I})$ salts and each protein (not purified) in eluent under argon atmosphere. The samples $\left(10^{-}\right.$ $169{ }^{4}, 10^{-5}$ and $10^{-6} \mathrm{~mol} \mathrm{~L}^{-1}$ of NaX, $4.610^{-6} \mathrm{~mol} \mathrm{~L}^{-1}$ of transferrin and $7.910^{-5} \mathrm{~mol} \mathrm{~L}^{-1}$ of albumin) were prepared by dilution in the appropriate eluent. $\mathrm{pH}$ was set to 2 by adding the appropriate volume of $\mathrm{HCl}$ to some samples of $\mathrm{NaX}$. The commercial serum was three times diluted in

172 the physiological-type eluent. The ${ }^{211}$ At stock solution in methanol was added to the solutions 173 with varying concentrations from $610^{-14}$ to $1.510^{-11} \mathrm{~mol} \mathrm{~L}^{-1}$. The mixtures were agitated for 2 $174 \mathrm{~h}$ at $25^{\circ} \mathrm{C}$ for equilibration.

175 The HPAEC method included a cleaning step by elution with $\mathrm{HCl}$, the $\mathrm{pH}$ shifting 176 gradually from 5 to 2 during $20 \mathrm{~min}$, followed by checking the resin stability. This was done 177 using $\mathrm{I}^{-}\left(10^{-5} \mathrm{~mol} \mathrm{~L}^{-1}\right)$ as internal standard giving a retention time of $11.2 \mathrm{~min}$ for a new AS20 178 column using $10^{-1} \mathrm{~mol} \mathrm{~L}^{-1} \mathrm{NaCl}$ at $350 \mu \mathrm{L} \min ^{-1}$. Over time, the shift of 0.6 min towards 179 lower retention time was observed which is explained by a small decrease of the site capacity 180 of the resin and was taken into account in the quantitative modeling (see 3 . Results and 181 discussion). Finally, the system was pre-equilibrated with the eluent of interest. The pre182 equilibration was controlled by measurement of $\mathrm{pH}$ and $\mathrm{E}$ at the inlet of the column and the 183 outlet of gamma detector. All experiments were performed under isocratic conditions at 25 $184{ }^{\circ} \mathrm{C}$. Samples were injected into the column through a $50 \mu \mathrm{L}$ sample loop injector. $\mathrm{I}^{-}$and $\mathrm{Br}^{-}$ 185 (both $10^{-5} \mathrm{~mol} \mathrm{~L}^{-1}$ ) were detected online spectrophotometrically at 230, $214 \mathrm{~nm}$, proteins and 186 blood serum at $280 \mathrm{~nm}$. An online detection of astatine was done by $\gamma$-ray detector. $\mathrm{F}^{-}\left(5 \times 10^{-5}\right.$ $187 \mathrm{~mol} \mathrm{~L}{ }^{-1}$ ) was detected offline (from collected fractions) by IC with conductivity detection. 
188 The recovery was determined from measurement of species' concentration before injection 189 and in the collected fractions.

190 For clarity in the data interpretation, the results are exploited as retention factors (k) with:

$191 \quad k=\frac{t_{R}-t_{D}}{t_{D}}$

$192 t_{R}$ and $t_{D}$ being the retention time and the dead time (corresponding to the method of detection used), respectively. When retention times are given, they refer to the position on the UV chromatogram.

\subsection{Quantitative analysis of experimental data}

PHREEQC is a 1D transport code [16] built for transport processes modeling including diffusion, advection and dispersion. All of these processes are combined with equilibrium and kinetic chemical reactions. Initially developed for modeling the transport of contaminants in soils, it is also well suited for the modeling of liquid chromatography data because the processes in analytical and environmental fields are likely identical. The input file, divided into three blocks, is briefly explained as follow.

The first block involves the aqueous speciation calculations. Using a chemical composition of each solution (potential, $\mathrm{pH}$, solutes and concentrations), it calculates the distribution of aqueous species using implemented thermodynamic databases. In the current study, the LLNL (Lawrence Livermore National Laboratory) thermodynamic database for F,

$210 \mathrm{Cl}, \mathrm{Br}$ and $\mathrm{I}$, and the recently reported data for At [21], were used for the modeling. All 211 equilibrium constants were extrapolated at zero ionic strength using the Truncated Davies 212 equation [22]. 
The second block involves the transport. As it will be experimentally shown latter, the

214 transport is imposed by the high pressure pump and can be considered as an advection process. The diffusion process, which affects the width of the elution peaks, was not considered since the paper is interested in the retention properties of the exchanger.

The third block describes the reaction at the surface of the exchanger. Ion-exchange being 218 an important mechanism occurring in soils, it is implemented in the code through the Gaines219 Thomas convention [23] which was used in the study. The approach uses the law of mass action, based on half-reactions between an aqueous species and a fictive unoccupied exchange 221 site for each exchanger. The reaction for the exchange species $\mathrm{S}-\mathrm{Cl}$ is:

$$
\mathrm{Cl}^{-}+\mathrm{S}_{\stackrel{+}{\leftarrow}} \mathrm{S}-\mathrm{Cl}
$$

223 where $\mathrm{S}^{+}$represents the exchange master species. Since all exchange sites are filled by 224 exchange species (the concentration of master species is forced to zero), the master species is 225 not included in the mole-balance equation for the exchanger. The activities of the exchange species are defined as equivalent fractions, being equal to the moles of sites occupied by an exchange species divided by the total number of exchange sites, in equivalents per $\mathrm{L}$ of

228 solution (when density $=1$ ). In $\mathrm{NaCl}$ medium, the exchange reaction of $\mathrm{X}^{-}(\mathrm{X}=\mathrm{F}, \mathrm{Br}, \mathrm{I}$ and 229 At) can be written as:

231 The distribution of species is given by the law of mass action:

$232 K_{X / C l}=\frac{\{S-X\}\left\{C l^{-}\right\}}{\left\{X^{-}\right\}\{S-C l\}}=\frac{K_{x}}{K_{C l}}$

233 Curly brackets indicate the activities, and $K_{X}$ and $K_{C l}$ the coefficients describing the 234 interaction between the specified anion $\mathrm{X}^{-}$and the exchange site $\mathrm{S}^{+}$according to the equation 235 (2). The exchange or selectivity coefficients $\mathrm{K}_{\mathrm{X} / \mathrm{Cl}}$ given in the paper are relative to $\mathrm{Cl}^{-}$, i.e. $236 K_{C l / C l}=1$. The activity coefficient for an exchange species is known to strongly depend on the 
exchanger composition and the ionic strength $[24,25]$. In the present study, the exchange 238 species corresponds to $\mathrm{S}-\mathrm{Cl}$ and the ionic strength is fixed to $10^{-1} \mathrm{~mol} \mathrm{~L}^{-1}$. We then fix the activity coefficient constants equal to 1 .

\subsection{Model development}

The system represented by the injection loop, tubing and columns is decomposed into a number of cells. Each cell is characterized by a given volume of water (whose composition is defined) and a given height. This simplistic representation of the system, the characteristics of which are given by DIONEX, is shown in Fig. 1. The model describes the void volume of a non-sorbing species, which corresponds to an UV peak at 2.4 min for a flux of $350 \mu \mathrm{L} \mathrm{min}{ }^{-1}$.

The difference in volume $(350 \mu \mathrm{L})$ between the two detectors was experimentally determined using both stable $\left({ }^{127} \mathrm{I}\right)$ and radioactive $\left({ }^{131} \mathrm{I}\right)$ iodide.

Fig. 1.

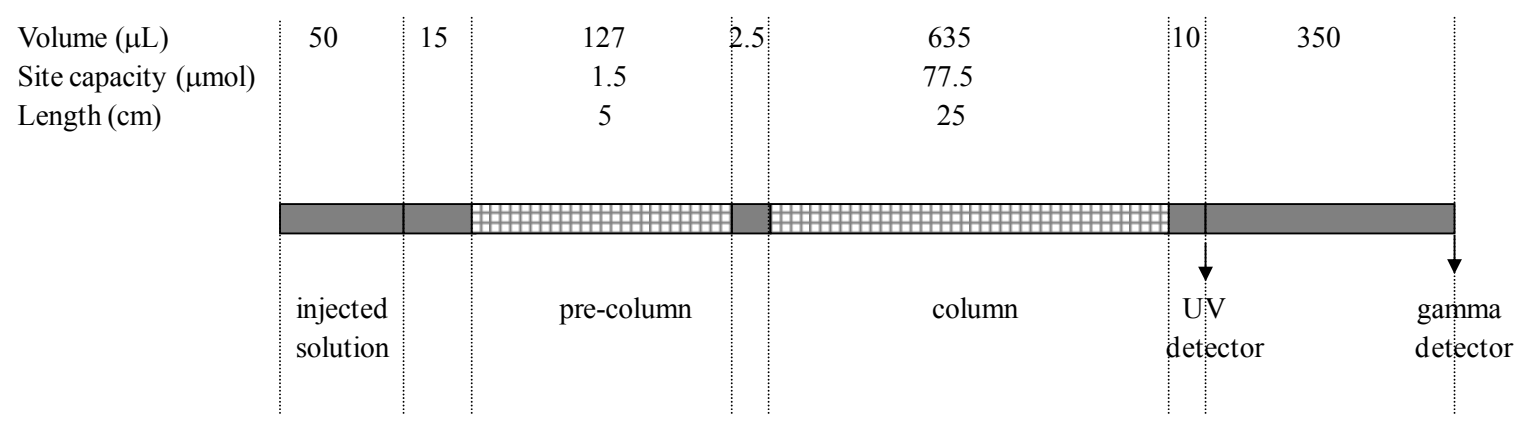

According to the ion-exchange reaction, sites (in mol) are added into the cells associated 255 to the exchanger. For each cell, the initial conditions and the set of reactants can be defined 256 individually, which provides flexibility to simulate a variety of chemical conditions 257 throughout the column. It is then possible to differentiate between the pre-column, the AG20 
guard column being packed with a resin of proportionally lower capacity, and the column

259 AS20. Nevertheless, in the model, it was assumed that the selectivity coefficients are identical

260 in both columns. Also, it was calculated that the guard column placed on-line prior to the 261 analytical column increases retention time of about $4 \%$. This value is in good agreement with 262 supplier's information.

263 The infilling solution for the column is always solution number 0. Advection is modeled 264 by "shifting" the solution 0 to cell 1 , the solution in cell 1 to cell 2 , and so on. At each shift, 265 equilibrium is maintained in each cell.

The model was first tested with trace amount of iodide $\left(10^{-4} \mathrm{~mol} \mathrm{~L}^{-1}\right)$ in $3.5 \times 10-^{1} \mathrm{~mol} \mathrm{~L}^{-1}$ $\mathrm{NaOH}$ medium. The experimental result has led to a retention factor $\mathrm{k}_{\mathrm{I}}$ of 2.3 . In such simple conditions (analyte occupies $<1 \%$ of the column capacity, exchange between two monovalent anions), the exchange coefficient can be simply calculated according to:

$K_{\mathrm{OH} / \mathrm{I}}=\frac{Q}{V_{m}\left\{\mathrm{OH}^{-}\right\}} \frac{1}{k_{I}}$

271 where $Q$ is the capacity of the column in meq, and $V_{m}$ is the dead volume of the column in $272 \mathrm{~mL}$. A value of 1.19 can be calculated (with $\mathrm{K}_{\mathrm{OH} / \mathrm{OH}}=1$ ) and agrees with the one derived from 273 PHREEQC. The input file used for the calculation is given in the supplementary information.

\section{RESULTS AND DISCUSSION}

\subsection{Characterization of $\mathrm{At}^{-}$}


A typical gamma chromatogram is presented in Fig. 2. It shows a significant retention of 283 astatine species on the anion exchanger with the retention time of $13 \mathrm{~min}$ and a recovery yield 284 between 70 and $100 \%$. It has been also settled that the retention of the astatine species is not 285 affected by the presence of methanol coming from astatine stock solutions. In a typical 286 experiment, the methanol content amounts to $2-5 \%$. When varying the content of methanol 287 from 1 even to $20 \%$ (in volume), no significant peak shift has been observed. This retention 288 did not prove that an anionic species exists and the exchange reaction has occurred. In a 289 recent work [26], some of us have shown that the cationic species of astatine existing under 290 acidic oxidizing conditions can be adsorbed on both anionic and cationic exchangers. This 291 peculiar behavior is related to the ultra-traces concentrations of astatine used in the 292 experiments.

Fig. 2.

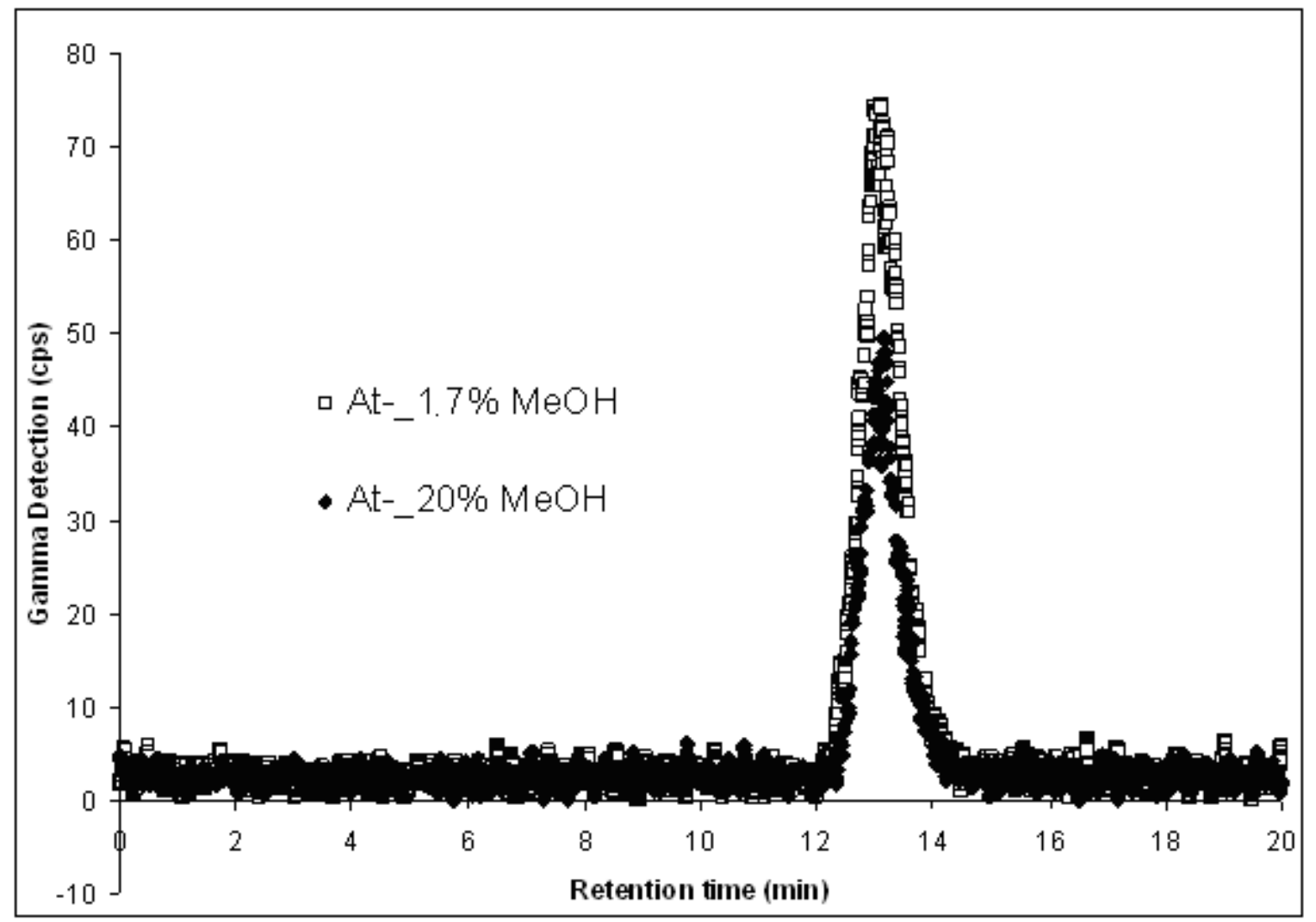


The quantitative analysis of further experimental data based on equation (3) has been 296 done. The competition effects for exchange sites were considered between chloride and 297 medium anions including astatine species. The competition with the hydroxide and the redox 298 couple $\mathrm{SO}_{3}{ }^{2-} / \mathrm{S}_{2} \mathrm{O}_{3}{ }^{2-}$ anions was neglected. In the first case, the concentration of $\mathrm{OH}^{-}$is too 299 weak for expecting a competition ( $\mathrm{pH}$ ranging between 2.0 and 7.5). In the second case, this 300 was checked experimentally: as shown in Fig. 3, the retention times of $\mathrm{I}^{-}$and $\mathrm{Br}^{-}$are similar in 301 the presence or absence of the redox couple anions. Fig. 3.

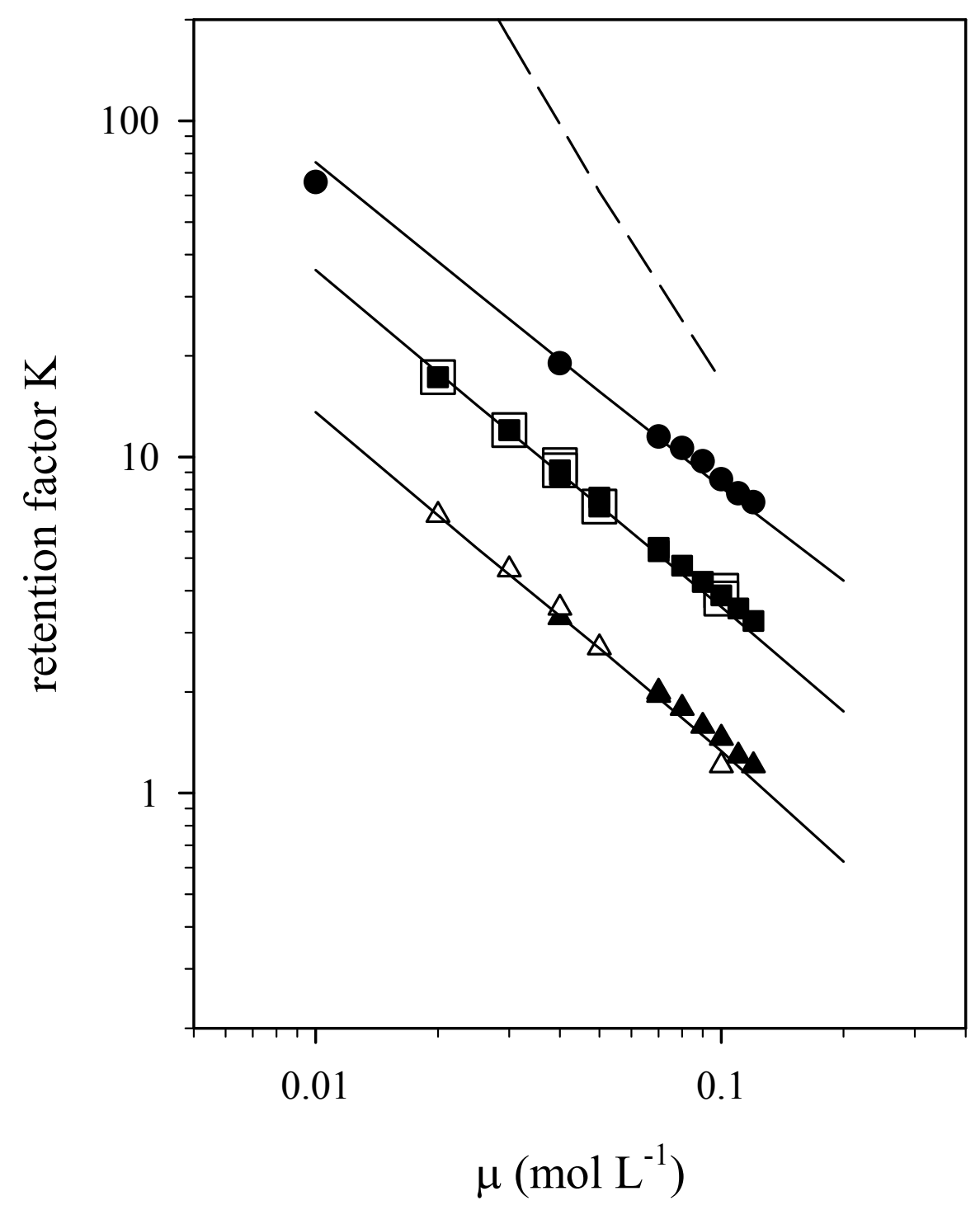


The determination of selectivity (exchange) coefficients requires modeling of the equilibrium at all stages of the column. In our dynamic system, the principle of "local equilibrium" was assumed, i.e. the rate of reactions was much more rapid than the rate of solute transport. It was checked for astatine considering the ultra traces concentrations of solute injected (about $3.8 \times 10^{8}$ atoms corresponding to a concentration at the outlet of the

309 column of $10^{-13} \mathrm{~mol} \mathrm{~L}^{-1}$ ). The conditions were considered as ideal when the flow rate was 310 below $500 \mu \mathrm{L} \mathrm{m^{-1 }}$, no change of the astatine retention factor was observed with the flow rate 311 (data not shown).

312 The influence of the ionic strength on the retention factor of $\mathrm{Br}^{-}, \mathrm{I}^{-}$and the astatine species 313 is shown on Fig. 3. The log-log representation of the retention factor as a function of the ionic 314 strength is linear. These experimental results are in agreement with the exchange process 315 principle. Moreover, the modeling fairly reproduces the experimental data if we attribute one 316 negative charge on astatine species. For illustration, the dashed line in Fig. 3 depicts the 317 behaviour of a species with two negative charges. Hence, the experimental data confirm the 318 existence of an anionic species with one negative charge.

319 The tendency for the relative selectivity coefficient of this species with respect to the 320 others halides was next questioned. Berei [5], using the data of Roessler [14], showed a linear 321 correlation within the halides series by plotting the retention volume as a function of the 322 inverse ionic radius and stated it as an indirect proof of the existence of $\mathrm{At}^{-}$. The same trend 323 should be found when plotting the relative selectivity coefficients as a function of the inverse 324 ionic radius.

325 The reported coefficients (Fig. 4) were compared with $\mathrm{K}_{\mathrm{X} / \mathrm{Cl}}$ recalculated from published retention volumes obtained with polystyrene-divinylbenzene anion exchange resins with 327 similar reactive sites [24] and those from retention factors specific for AS20 given by the 
328 Virtual Column Separation Simulator 2 [27]. Note that values are given with respect to $\mathrm{OH}^{-}$

329 and the relative selectivity coefficients $\mathrm{K}_{\mathrm{X} / \mathrm{Cl}}$ were recalculated according to:

330

$$
K_{X / C l}=\frac{K_{X / O H}}{K_{C / O H}}
$$

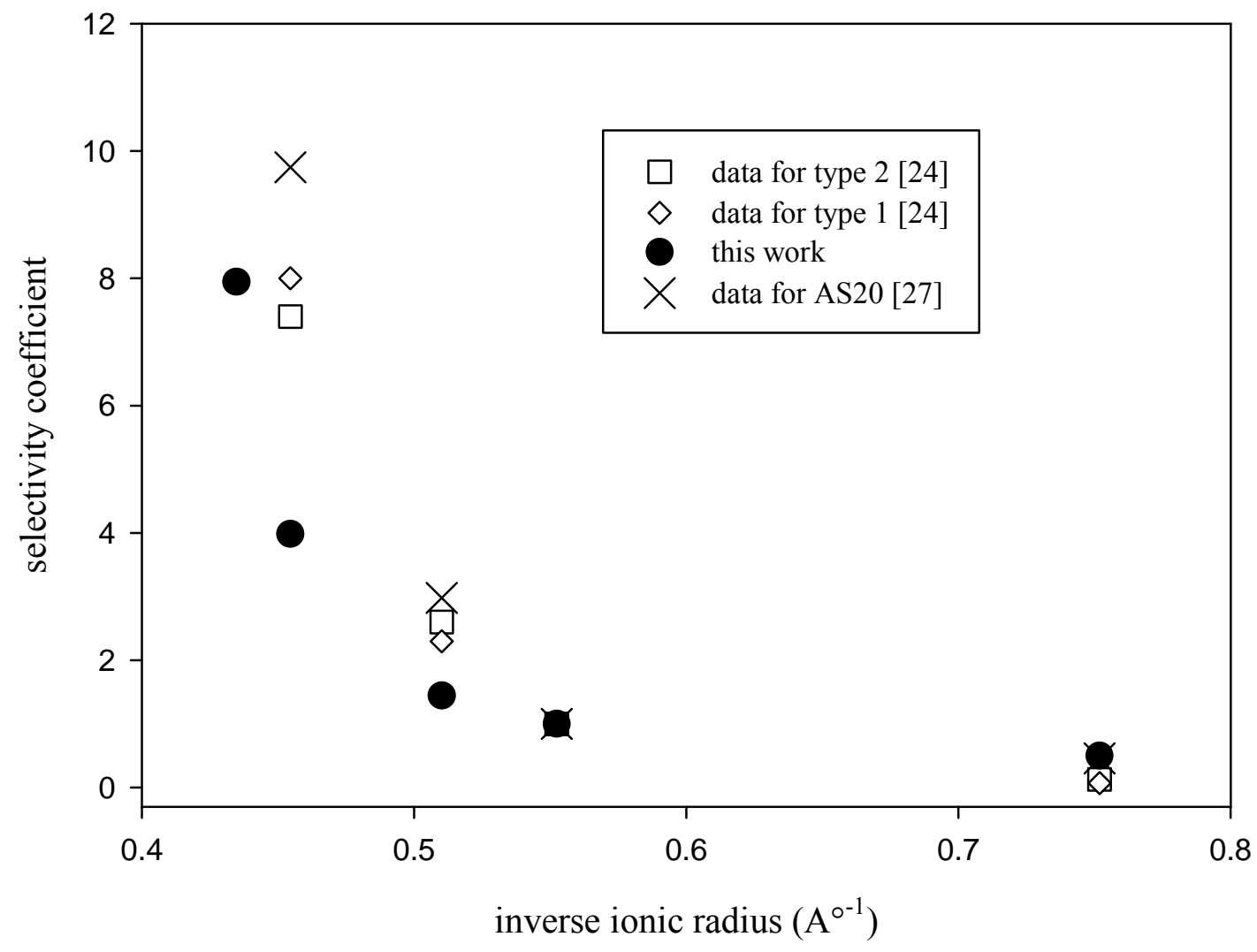

On the one hand, as shown in Fig. 4, the $K_{X / C l}$ values determined in the present work in

334 chloride medium are not identical with the $K_{X / C l}$ derived from hydroxide medium for AS20

335 and polystyrene-divinylbenzene anion exchangers. A correction of the activity coefficients for

336 the exchange species would be necessary, since the medium strongly influences the values of

337 selectivity coefficients [25]. Also, the differences may be explained by means of hydrophilic

338 character of resins: AS20 is highly hydrophilic while polystyrene-divinylbenzene resin is less

339 hydrophilic [28]. 
On the other hand, all plots of the relative selectivity coefficients as a function of the inverse ionic radius show an exponential-type curve. The empirical law of Berei [5] appears

342 therefore to be not valid and could not demonstrate the existence of $\mathrm{At}^{-}$. One can only

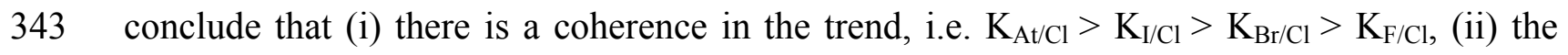
344 species holds one negative charge, and (iii) the existence of an oxyanion is unlikely as it 345 would not explain the data published in our previous work [21]. All results and the behaviour 346 of astatine discussed in the introduction, provide an indirect proof of the existence of At ${ }^{-}$

\subsection{Astatine speciation in blood serum}

The behaviour of astatine in serum has been then investigated. The usual techniques of speciation of trace elements in biological environment were reviewed by Lobinski [29]. In the present case, the speciation of astatine in serum has been performed using HPAE- $\gamma$ system with the aims to simulate the equilibrium of astatine in blood serum and to monitor astatine species formed under physiological serum conditions.

In order to minimize external perturbation on the equilibrium in serum, the physiological358 type mobile phase containing $10^{-1} \mathrm{~mol} \mathrm{~L}^{-1}$ of $\mathrm{NaCl}, 10^{-3} \mathrm{~mol} \mathrm{~L}^{-1}$ of PBS buffer and $10^{-4} / 10^{-3}$ mol L $\mathrm{L}^{-1}$ of $\mathrm{SO}_{3}{ }^{2-} / \mathrm{S}_{2} \mathrm{O}_{3}{ }^{2-}$ redox buffer has been prepared. The effect of the major serum 360 components (transferrin, albumin, monovalent carbonate anion $\mathrm{HCO}_{3}{ }^{-}$and citrate) on $\mathrm{At}^{-}$ 361 elution was studied in model media before working with the biological medium. The 362 investigated constituent is injected into the column and chloride competing agent is in mobile 363 phase. The retention of a solute on the column is clearly related to the exchange reaction as 364 described in equation (3) when $\mathrm{X}^{-}=$albumin, transferrin, PBS. For mixture containing 
astatine, the simple comparison of the retention with the $\gamma$-chromatograph from previous part

366 of this study without any exchange evaluation has been done.

\subsubsection{UV-characterization of major components in serum}

The UV-chromatogram of the blood serum is given in Fig. 5. Three peaks at 2.5, 7.7 and 10.5 min could be identified. The first peak eluted almost in the void volume (2.3 min) was

374 identified as the peak of transferrin (Fig. 5B). The protein, dissolved in the physiological-type 375 of eluent, was not retained on AS20 resin. Thus it is not expected to compete with astatine species for sorption sites. The broad peak at 10.3-11.0 min coincides with the elution of albumin which was dissolved in the synthetic physiological-type medium in the presence of 378 transferrin (grey line in Fig. 5). The large full width at half maximum of the peak is explained by the presence of a mixture of the monomer and dimer of albumin. Whereas a better separation of monomer and dimer was obtained at a flow rate of $500 \mu \mathrm{L} \mathrm{min}^{-1}$, the resultant 381 pressure exceeded the limit of the column. In synthetic media, $75-80 \%$ of the proteins were 382 found at the exit of the column, while the restitution was lower (50-60\%) in the case of the 383 serum. Obviously, the AS20 resin allows the resolution of both important metallo-proteins in 384 "non-perturbing" conditions. Transferrin elutes nearly in the void volume while albumin is significantly retained on stationary support. The albumin retention has been quantitatively 386 explained by an apparent selectivity coefficient $K_{\text {Albumin/Cl }}=0.15$ for exchange of $\mathrm{Cl}^{-}$and one 387 negative charge of albumin.

$388 \quad$ Fig. 5. 


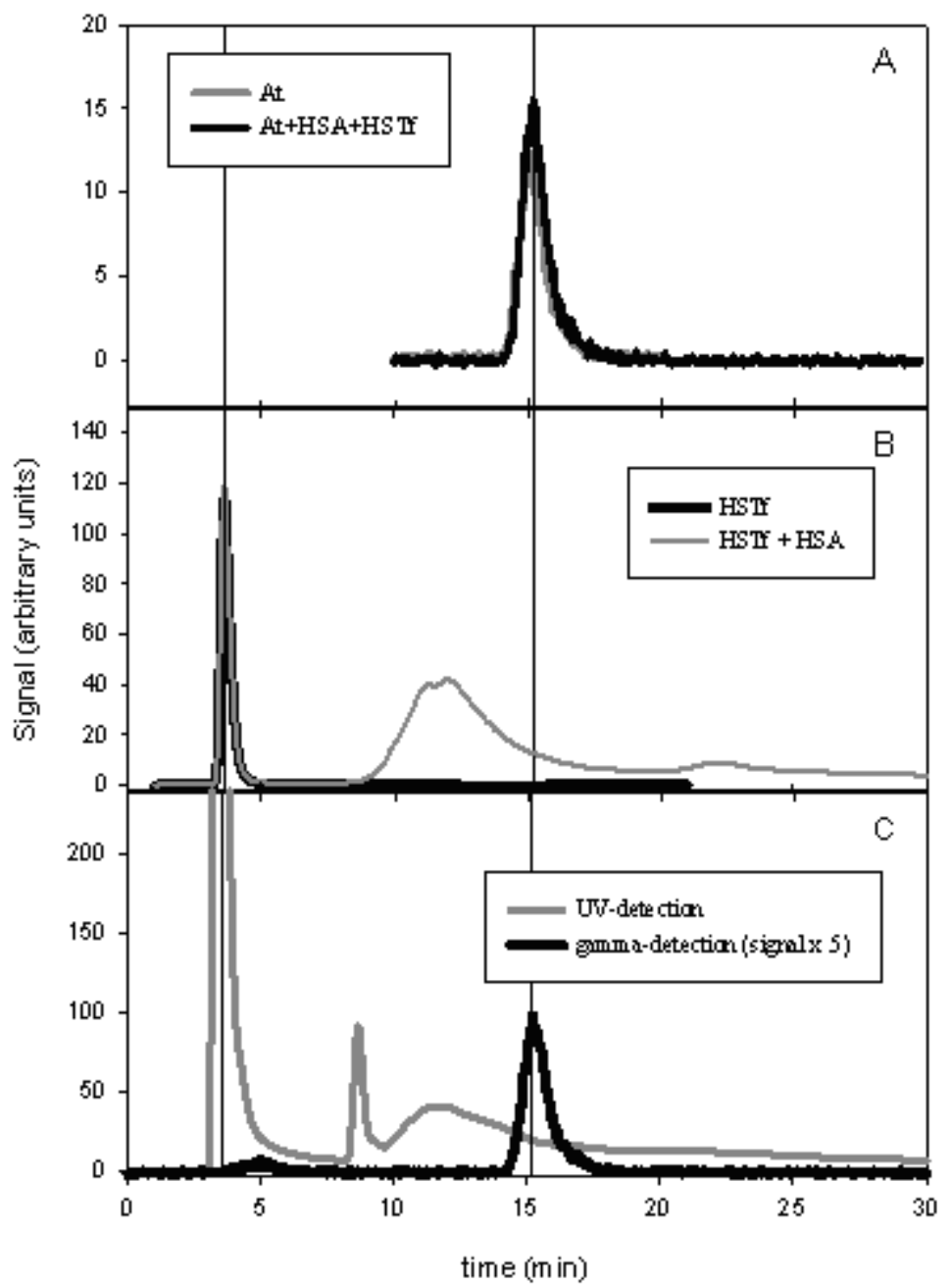

The experiments with the two main anionic low molecular weight components 391 (bicarbonate $\mathrm{HCO}_{3}{ }^{-}$and citrates $\mathrm{C}_{3} \mathrm{H}_{5} \mathrm{O}(\mathrm{COO})_{3}{ }^{3-}$ ) did not allow us to identify the peak eluted 392 at $7.7 \mathrm{~min}$. Considering the complexity of the serum, this may be associated to the presence of 393 another low molecular weight molecule with high absorption extinction coefficient but 394 present in low amount. Therefore, it was not considered as a probable interfering species in a 395 first assumption. No further experiments were done for identifying it. 
The At ${ }^{-}$peak in the physiological-type medium was initially expected from modeling at 402 the retention time of 15.3 min with a retention factor of 8.6 , considering the previously determined selective coefficients and experimental conditions (electrolyte composition, $\mu, \mathrm{pH}$ and potential). The peak has appeared on the gamma chromatogram (Fig. 5) at the retention time of 15.3 min with a retention factor of 5.4 and a restored yield of $100 \%$.

The damage of the resin over time leading to a decrease in the number of sites was 407 therefore considered. The regular column tests done with iodide (see 2. Experimental section) 408 have given a retention factor of 3.3 , instead of 3.7 for a new column. This shift quantitatively explains $10 \%$ of decrease in retention sites number. This may result from a damage of the resin through the irradiation of alpha particles which are highly energetic. The model 411 parameterization was changed accordingly for the further data evaluation.

412 However, the decrease of $10 \%$ sorption capacity of the resin can only partially explain the astatine shift because the retention factor would lower from 8.6 to 7.8. Complementary experiments with $\mathrm{I}^{-}$under physiological type-conditions (in presence of PBS) were done. A

415 decrease in retention factor is observed as compared to the one determined with $0.1 \mathrm{~mol} \mathrm{~L}^{-1}$ $416 \mathrm{NaCl}$ as eluent (2.6 instead of 3.3). This peak shift has evidenced that the PBS buffer compete 417 with $\mathrm{X}^{-}$for sorption sites. In agreement with this assumption, the experimentally determined 418 retention factors of $\mathrm{I}^{-}(3.3)$ and $\mathrm{At}^{-}$(5.4) can truly be predicted using the previously 419 determined coefficients $K_{A t / C l}$ and $K_{I / C l}$ and including $\log K_{P B S / C l}=1.7 \pm 0.1$.

420 Transferrin and especially albumin represent the main potential competing agents in the 421 blood medium. However, as Fig. 5A shows, no competition has occurred with proteins at the 422 concentration encountered in the blood serum: in the presence and absence of proteins, the retention volumes of $\mathrm{At}^{-}$are identical. This was also predicted using previously determined 424 selectivity coefficients $K_{A l b u m i n / C l}, K_{A t / C l}$ and $K_{P B S / C l}$. A similar result was obtained when 425 carbonates and citrate ions were added to astatine solutions (data not shown). These results 
show that $\mathrm{Cl}^{-}$and phosphates present in the eluent exclusively govern the competition and that no interaction between $\mathrm{At}^{-}$and major serum components occurs. than the one observed in the physiological-type medium (Fig. 5A and Fig. 5C), and was restored more than $75 \%$. This result can be seen as a genuine proof of the existence of $\mathrm{At}^{-}$in the blood serum. The species was however restored at a yield slightly lower than those found with the physiological-type media. The presence of an additional cationic or neutral astatine species in weak amount strongly retained on the tubing of the HPAEC device cannot be excluded.

\section{CONCLUSION}

The usefulness of HPAEC $-\gamma$ to get information regarding astatine speciation in simple and synthetic media, provided that a careful quantitative analysis is done, has been

442 established. We report the first analytical result characterizing At: the species is anionic, 443 holds one charge and its behavior is coherent in the halide series. A selectivity coefficient $444 \mathrm{~K}_{\mathrm{At} / \mathrm{Cl}}$ is given for the studied column. The methodology was successfully applied to 445 biological medium. The resin used appears useful to separate the two important metallo 446 proteins. Similar results with astatine were obtained in physiological-type and blood serum 447 media; this indicates no interaction between astatine and serum components. In reducing 448 conditions, astatine mainly exists as $\mathrm{At}^{-}$in the blood serum. This is in agreement with in-vivo 449 data found in the literature, i.e. astatide is attracted to the thyroid as $\mathrm{I}^{-}$is [30]. The 450 methodology is an alternative to the thin layer chromatography generally used for the in vitro 
451 stability assessment of ${ }^{211}$ At-labelled molecules. Based on our results, the appearance of a 452 peak corresponding to a retention factor of 5.3 would indicate the presence of astatide 453 released from radio-labelled molecule, i.e. the binding between ${ }^{211}$ At and the carrier molecule 454 in the sample incubated in the blood serum is not enough strong to compete with the 455 formation of the thermodynamically stable astatide species in blood serum.

\section{ACKNOWLEDGEMENT}

The authors would like to thank the "Agence Nationale de la Recherche" (ANR, 462 JCJC06_137852 and ANR-10-BLANC-0807), the "Région Pays de la Loire" (NUCSAN 463 project and the grant allocated to Julie Champion), the scientific committee of the FR CNRS 4643173 "GRIM3" and the European Commission (TARCC project) for financial support. The 465 authors are also grateful to CEMTHI team, especially to Isidro Da Silva, for the production of $466{ }^{211}$ At. We would like to address special thanks to Prof. Alain Faivre-Chauvet for providing $467{ }^{131}$ I and to Prof. Geerd-J. Meyer for fruitful discussion. Also, we thank DIONEX for having 468 given us the data from the Virtual Column program and Anne-Marie Compiano to have read 469 again the article. 


\section{FIGURE CAPTIONS}

Fig. 1. Parameters used for the simulation (1D dimension).

Fig. 2. Effect of the methanol content in the injected sample (in weigh percent) on the elution 478 profile of astatine at $350 \mu \mathrm{L} \mathrm{min}{ }^{-1}$; eluent at $\mathrm{pH} 2$ contains $0.1 \mathrm{~mol} \mathrm{~L}^{-1}$ of $\mathrm{NaCl}, 10^{-2} \mathrm{~mol} \mathrm{~L}^{-1}$ of $\mathrm{HCl}$, and $10^{-4} / 10^{-3} \mathrm{~mol} \mathrm{~L}^{-1}$ of $\mathrm{SO}_{3}{ }^{2-} / \mathrm{S}_{2} \mathrm{O}_{3}{ }^{2-}$.

Fig. 3. HPAEC results for $\mathrm{At}^{-}$(circles), $\mathrm{I}^{-}$(squares) and, Br- (triangles); the flow rate was

482 fixed between 350 and $450 \mu \mathrm{L} \mathrm{m^{-1 }}$. Filled symbols: $0.1 \mathrm{~mol} \mathrm{~L}^{-1} \mathrm{NaCl}$; open symbols: $10^{-2}$ $483 \mathrm{~mol} \mathrm{~L}^{-1}$ of $\mathrm{HCl}, 10^{-4} / 10^{-3} \mathrm{~mol} \mathrm{~L}^{-1}$ of $\mathrm{SO}_{3}{ }^{2-} / \mathrm{S}_{2} \mathrm{O}_{3}{ }^{2-}$ and $10^{-1} \mathrm{~mol} \mathrm{~L}^{-1}$ of $\mathrm{NaCl}$. The lines are 484 calculated with $\log K_{X / C l}$ values of $0.16,0.58$ and 0.90 for $\mathrm{Br}^{-}, \mathrm{I}^{-}$and $\mathrm{At}^{-}$, respectively. The 485 dashed line represents a prediction considering that astatine species holds two negative 486 charge.

Fig. 4. Variation of relative exchange selectivity coefficients for quaternary ammonium ions exchange resins as a function of the inverse ionic radii for the halides series. The filled and open symbols depict the data measured in this work and the published one [27] found for a

491 similar type of resin, respectively. The selectivity coefficient for $\mathrm{F}^{-}$was deduced from an 492 experiment giving an elution time of 8 min (eluent: $5 \times 10^{-2} \mathrm{~mol} \mathrm{~L}^{-1} \mathrm{NaCl}$; flow rate: $200 \mu \mathrm{L}$ $\left.493 \mathrm{~min}^{-1}\right)$.

Fig. 5. Speciation of astatine in human serum. (A) $\gamma$-chromatogram of astatine in the presence or absence of transferrin and albumin proteins (signal multiplied by a factor of 5 to 
1. D. R. Fisher, Curr. Radiopharm. 1 (2008) 127-134.

2. D. S. Wilbur, Curr. Radiopharm. 3 (2008) 144-176.

3. G. Vaidyanathan, M. R. Zalutsky, Curr. Radiopharm. 1 (2008) 177-196.

4. S. Lindegren, S. Frost, T. Back, E. Haglund, J. Elgqvist and H. Jensen, J. Nucl. Med. 49 (2008) 1537-1545.

5. K. Berei, L. Vasaros, Astatine Compounds, $8^{\text {th }}$ ed., Springer-Verlag, Berlin, 1985.

6. K. Berei, L. Vasaros, in: S. Patai and Z. Rappoport (Eds.), The chemistry of halides, pseudo-halides and azides, John Wiley \& Sons Ltd., New York, 1995, pp. 787-819.

7. D. S. Wilbur, M.-K. Chyan, D. K. Hamlin and M. A. Perry, Bioconjugate Chem. 20 (2009) 591-602.

8. T.C. Richardson, Int. J. Appl. Rad. Instrum. B 13 (1986) 583-584.

9. G. L. Johnson, R. F. Leininger and E. Segre, J. Chem. Phys. 17 (1949) 1-10.

10. V. D. Nefedov, Y. V. Norseev, M. A. Toropova and V. A. Khalkin, Russ. Chem. Rev. 2 (1968) 87-98.

11. E. H. Appelman, E. N. Sloth and M. H. Studier, Inorg. Chem. 5 (1966) 766-769.

12. A. Cavallero and K. Rossler, Radiochim. Acta 47 (1989) 113-117.

13. Meyer, Chromatographie trägerfreier anorganisher Formen von Jod-123 und Astat211 und ihre Verwendung zur Halogenierung von Uracil and Desoxyuridin, Berichte Nr.1076, Kernforschungsanlage Jülich, Jülich, 1974.

14. K. Roessler, W. Tornau and G. Stoecklin, J. Radioanal. Chem. 21 (1974) 199-209.

15. R. Dreyer, I. Dreyer, F. Rosch and G. J. Beyer, Radiochem. Radioanal. Lett. 54 (1982) 165-175.

16. D. L. Parkhurst, C. A. J. Appelo, User's guide to phreeqc - a computer program for speciation, batch-reaction, one-dimensional transport, and inverse geochemical calculations, USGS Report No. 99-4259,1999.

17. E. Ansoborlo, O. Prat, P. Moisy, C. Den Auwer, P. Guilbaud, M. VCarriere, B. Gouget, J. Duffield, D. Doizi, T. Vercouter, C. Moulin, V. Moulin, Biochimie 88 (2006) 1605-1618.

18. C. Alliot, M. Chérel, J. Barbet, T. Sauvage, G. Montavon, Radiochim. Acta 97 (2009) 161-165.

19. S. Lindegren, T. Back, H. J. Jensen, Appl. Radiat. Isot. 55 (2001) 157-160.

20. H. Sun, K. Y. Szeto, J. Inorg. Biochem. 94 (2003) 114-120.

21. J. Champion, C. Alliot, E. Renault, B. M. Mokili, M. Chérel, N. Galland and G. Montavon, J. Phys. Chem. A 114 (2010) 576-582.

22. C. W. Davies, Ion association, Butterworths, Washington D.C., 1962.

23. G. L. Gaines, H. C. Thomas, J. Chem. Phys. 21 (1953) 714-718.

24. F. de Dardel, Techniques de l'ingénieur, J2 783-782-716 (1998) 1-16.

25. B. Trémillon, Les séparations par les résines échangeuses d'ions, Gauthier-Villars, Paris, 1965.

26. J. Champion, C. Alliot, S. Huclier, D. Deniaud, Z. Asfari, G. Montavon, Inorg. Chim. Acta 362 (2009) 2654-2661.

27. J. E. Madden, M. J. Shaw, G. W. Dicinoski, N. Avdalovic, P. R. Haddad, Anal. Chem. 74 (2002) 6023-6230.

28. C. Liang, C. A. Lucy, J. Chromatogr. A 1217 (2010) 8154-8160.

29. R. Lobinski, C. Moulin, R. Ortega, Biochimie 88 (2006) 1591-1604.

30. D. S. Wilbur, Bioconjugate Chem. 19 (2008) 158-170. 
552

553 